Headquarters: POB 995, A-1011 Vienna, Austria.

Website: http://www.opecfund.org

email:info@ofid.org

Director-General: Suleiman Jasir al-Herbish (Saudi Arabia).

\section{Antarctic Treaty}

Antarctica is an island continent some $15.5 \mathrm{~m}$. sq. $\mathrm{km}$ in area which lies almost entirely within the Antarctic Circle. Its surface is composed of an ice sheet over rock, and it is uninhabited except for research and other workers in the course of duty. It is in general ownerless: for countries with territorial claims, see ARGENTINA; AUSTRALIA: Australian Antarctic Territory; CHILE; FRANCE: Southern and Antarctic Territories; NEW ZEALAND: Ross Dependency; NORWAY: Queen Maud Land; UNITED KINGDOM: British Antarctic Territory.

12 countries which had maintained research stations in Antarctica during International Geophysical Year, 1957-58 (Argentina, Australia, Belgium, Chile, France, Japan, New Zealand, Norway, South Africa, the USSR, the UK and the USA) signed the Antarctic Treaty (Washington Treaty) on 1 Dec. 1959. Austria, Belarus, Brazil, Bulgaria, Canada, China, Colombia, Cuba, Czech Republic, Denmark, Ecuador, Estonia, Finland, Germany, Greece, Guatemala, Hungary, India, Italy, South Korea, North Korea, the Netherlands, Papua New Guinea, Peru, Poland, Romania, Slovakia, Spain, Sweden, Switzerland, Turkey, Ukraine, Uruguay and Venezuela subsequently acceded to the Treaty. The Treaty reserves the Antarctic area south of $60^{\circ} \mathrm{S}$. lat. for peaceful purposes, provides for international co-operation in scientific investigation and research, and preserves, for the duration of the Treaty, the status quo with regard to territorial sovereignty, rights and claims. The Treaty entered into force on 23 June 1961. The 46 nations party to the Treaty ( 28 full voting signatories and 18 adherents) meet biennially.

An agreement reached in Madrid in April 1991 and signed by all 39 parties in Oct. imposes a ban on mineral exploitation in Antarctica for 50 years, at the end of which any one of the 28 voting parties may request a review conference. After this the ban may be lifted by agreement of three quarters of the nations then voting, which must include the present 28 .

Headquarters: Av. Leandro Alem 884-4º Piso, C1001AAQ,

Buenos Aires, Argentina.

Website: http://www.ats.aq/

email: secret@ats.aq

Executive Secretary: Johannes Huber (Netherlands).

\section{Further Reading}

Elliott, L. M., International Environmental Politics: Protecting the Antarctic. London, 1994

Jørgensen-Dahl, A. and Østreng, W., The Antarctic Treaty System in World Politics. London, 1991

Meadows, J., et al., The Antarctic [Bibliography]. Oxford and New Brunswick (NJ), 1994

\section{United Nations Framework Convention on Climate Change}

The convention was produced at the 1992 UN Conference on Environment and Development with the stated aim of reducing global greenhouse gas emissions to 'a level that would prevent dangerous anthropogenic (human induced) interference with the climate system'. Signatories agreed to take account of climate change in their domestic policy and to develop national programmes that would slow its progress. However, no mandatory targets were established for the reduction of emissions so the treaty remained legally non-binding. Instead it operates as a 'framework' document, with provisions for regular updates and amendments.

The first of these additions was the Kyoto Protocol in 1997. Under the protocol, 36 developed countries are committed to reducing their collective emissions of six greenhouse gases to at least 5\% below 1990 levels. These targets are scheduled to be met in the period 2008-12. A degree of flexibility is provided by the system of 'market-based mechanisms' that allows parties to earn and trade emissions credits. By Feb. 2008, 174 countries had signed and ratified the treaty. The USA has not ratified the protocol. China and India, also amongst the world's top five producers of emissions, are exempt from the protocol's constraints by virtue of their status as developing countries.

The members of the UNFCCC meet on an annual basis. The most recent conference in Indonesia in Dec. 2007 led to the creation of the 'Bali Roadmap', which timetables negotiations for a protocol to succeed Kyoto. The next meeting of the UNFCCC is scheduled to take place in Poznań, Poland in Dec. 2008.

Headquarters: United Nations Framework Convention on Climate Change, Haus Carstanjen, Martin-Luther-KingStrasse 8, D-53175 Bonn, Germany.

Website: http://unfccc.int

email:secretariat@unfccc.int

Executive Secretary: Yvo de Boer (Netherlands).

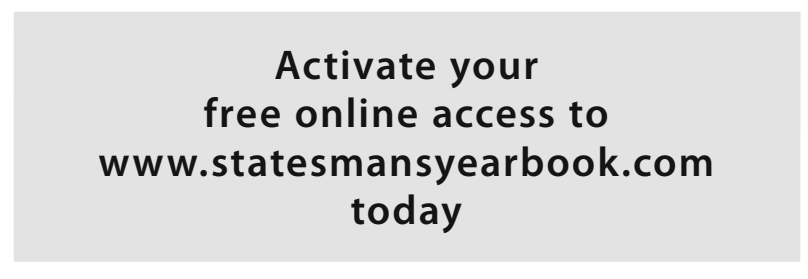

